\title{
Effectiveness of adding vildagliptin to the treatment of diabetic patients nonresponsive to the combination of metformin and a sulphonylurea
}

\author{
Eficácia da adição de vildagliptina ao tratamento de \\ pacientes diabéticos não responsivos à combinação \\ de metformina e uma sulfonilureia
}

Lucio Vilar ${ }^{1,2}$, Amaro Gusmão ${ }^{1,2}$, José Luciano Albuquerque ${ }^{2}$, Lisete Pontes'2, Larissa Montenegro'2, Soraya Pontes², George Robson Ibiapina²,

Rodrigo Andrade Cunha ${ }^{2}$, Gercivan dos Santos Alves², Viviane Canadas², Vera Maria Santos G. Ferreira ${ }^{2}$, Lucia Helena Coelho Nóbrega ${ }^{3}$, Josivan Gomes de Lima ${ }^{3}$

${ }^{1}$ Center for Diabetes and Endocrinology of Pernambuco, Recife, PE, Brazil

${ }^{2}$ Endocrinology Service, Hospital das Clínicas, Universidade Federal de Pernambuco (UFPE), Recife, PE, Brazil ${ }^{3}$ Center for Endocrinology of Natal, Natal, RN, Brazil
Correspondence to: Lucio Vilar

Rua Clovis Silveira Barros, 84/1202 50050-270 - Recife, PE, Brazil Ivilarf@mail.com

Received on Aug/18/2010 Accepted on Apr/26/2011

\begin{abstract}
Objective: To evaluate the effectiveness of adding vildagliptin to the treatment of patients with inadequately controlled type 2 diabetes mellitus (T2DM) treated with a combination of metformin and a sulphonylurea. Subjects and methods: 37T2DM patients with $\mathrm{HbA} 1 \mathrm{c}$ ranging from $7.7 \%$ to $12.4 \%$ (mean of $9.30 \pm 1.38$ ), despite the use of metformin in combination with a sulphonylurea, were additionally treated with vildagliptin (100 mg/day) for at least 6 months. Results: During triple oral therapy (TOT) HbA1c levels < 7\% were achieved in 11 patients $(29.7 \%)$, whereas levels of fasting plasma glucose (FPG) $<120 \mathrm{mg} / \mathrm{dL}$ were observed in 12 patients $(32.4 \%)$. Both findings were observed in 10 patients $(27.0 \%)$. Compared to nonresponsive subjects, lower mean baseline $\mathrm{HbA} 1 \mathrm{c}$ and FPG levels were seen in responsive patients, but the difference was only statistically significant for fasting plasma glucose (FPG). Moreover, there was considerable overlap between the two groups. Conclusion: Our preliminary results suggest that TOT with metformin, a sulphonylurea and vildagliptin may be useful for some T2DM patients nonresponsive to combination therapy with metformin and sulphonylurea. Arq Bras Endocrinol Metab. 2011;55(4):260-5
\end{abstract}

Keywords

Metformin; sulphonylurea; vildagliptin; triple oral therapy

\section{RESUMO}

Objetivo: Avaliar a eficácia da adição de vildagliptina ao tratamento de pacientes com diabetes melito tipo 2 (DM2) inadequadamente controlados com a terapia de combinação com metformina e sulfonilureia. Sujeitos e métodos: 37 pacientes com DM2 e HbA1c variando entre $7,7 \%$ e 12,4\% (média, 9,30 $\pm 1,38$ ), apesar do uso de metformina associada a uma sulfonilureia, foram adicionalmente tratados com vildagliptina ( $100 \mathrm{mg} / \mathrm{dia}$ ) durante, pelo menos, 6 meses. Resultados: Durante a terapia oral tripla (TOT), níveis de $\mathrm{HbA} 1 \mathrm{c}<7 \%$ foram alcançados em 11 pacientes $(27,9 \%$ ), enquanto a glicemia de jejum (GJ) $<120 \mathrm{mg} / \mathrm{dL}$ foi observada em 12 pacientes $(32,4.1 \%)$. Ambos os resultados foram descritos em 10 pacientes (27,0\%). Em comparação com indivíduos não responsivos, os pacientes responsivos tinham níveis basais mais baixos de $\mathrm{HbA} 1 \mathrm{c}$ e $\mathrm{GJ}$, mas a diferença foi estatisticamente significativa somente para glicemia de jejum. Além disso, houve grande sobreposição entre os dois grupos. Conclusão: Nossos resultados preliminares sugerem que aTOT com metformina, uma sulfonilureia e vildagliptina pode ser útil para alguns pacientes com DM2 não responsivos à combinação com metformina e uma sulfonilureia. Arq Bras Endocrinol Metab. 2011;55(4):260-5

Descritores

Metformina; sulfonilureia; vildagliptina; terapia oral tripla 


\section{INTRODUCTION}

$\mathrm{T}$ The main pathophysiologic mechanisms of hyperglycemia in type 2 diabetic patients involve insulin resistance, impaired insulin secretion, and increased hepatic glucose output (1-3). It was also shown that glucagon-like peptide 1 (GLP-1) deficiency is another key component of type 2 diabetes (T2DM) pathogenesis $(4,5)$. This incretin is a naturally occurring hormone that is released from gut cells in response to food. Once in the circulation, GLP-1 has a half-life of less than 2 minutes, due to rapid degradation by the enzyme dipeptidyl peptidase-4 (DPP-4). GLP-1 is a potent antihyperglycemic hormone, inducing glucose-dependent stimulation of insulin secretion by beta cells, while suppressing glucagon secretion by pancreatic alpha cells (1,4-6).

The three main options among oral glucose-lowering drugs are metformin, sulphonylureas and thiazolidinediones (TZDs) (7-10). More recently, DPP-4 inhibitors, such as vildagliptin, sitagliptin and saxagliptin, became commercially available (11-13). All these drugs may be used as monotherapy, but most patients with type 2 diabetes will eventually require a combination of two or more antidiabetic agents in order to achieve adequate glycemic control (14-16). The most commonly used triple oral therapy includes the combination of metformin with a sulphonylurea and a $\operatorname{TZD}(7,16)$. A triple oral combination including a DPP-4 inhibitor would have several theoretical advantages but, at present, it has not been supported by any published trial.

The aim of the present study was to assess the effectiveness of adding vildagliptin to the treatment of patients with type 2 diabetes without appropriate glycemic control, despite the use of combination therapy with metformin and a sulphonylurea.

\section{SUBJECTS AND METHODS}

\section{Patients}

Thirty seven patients (21 women and 16 men; mean age, $45.3 \pm 5.5$ years; age range, $38-58$ ) with type 2 diabetes were included in this prospective open trial. Patients were selected from outpatients in the Center for Diabetes and Endocrinology of Pernambuco, Reci$\mathrm{fe}$, Brazil. The main inclusion criterion was poor glycemic control (glycated hemoglobin [HbAlc] > 7.0\%), despite the combination therapy with metformin and a sulphonylurea.

\section{Study design and assays}

The study was performed in accordance with the declaration of Helsinki, and was approved by the local ethics committee. All participants provided informed consent before enrolling in the study.

The main objective of the current study was to evaluate the efficacy of adding vildagliptin to patients with type 2 diabetes without appropriate glycemic control, despite the use of combination therapy with metformin and a sulphonylurea. Vildagliptin (100 mg/day) was prescribed for at least 6 months to patients whose combination therapy with metformin (1,700-2,550 mg/ day) and a sulphonylurea - either gliclazide MR (30-90 $\mathrm{mg} /$ dia), glibenclamide (10-20 mg/day) or glimepiride $(4 \mathrm{mg} /$ day $)$ - was not able to maintain HbAlc levels $<7 \%$.Patients who achieved HbAlc levels $<7 \%$ after the addition of vildagliptin were labeled responsive, whereas those who did not were considered nonresponsive.

Body mass index (BMI), fasting plasma glucose (FPG) and HbAlc were evaluated at baseline and every three months afterwards. All plasmatic parameters were determined after a 12-hour overnight fast. Venous blood samples were collected from all patients between 8 a.m. and 9 a.m. Plasma glucose was measured by an immunoturbidimetric method using a commercial kit (Selectra Merck), with intra- and inter-assay coefficients of variation $(\mathrm{CV})<2 \%$. HbAlc levels were measured by high-performance liquid chromatography (DIAMAT, Bio-Rad, USA; normal values, 4.0\%-6.0\%), with intraand inter-assay $\mathrm{CV}<2 \%$. BMI were calculated as weight in kilograms divided by the square of height in meters.

\section{Statistical analysis}

In the analysis of qualitative variables, $\chi^{2}$ test or Fisher's exact test were used whenever necessary. Student's t-test or analysis of variance (ANOVA) were performed for comparative analysis of quantitative variables. Results are presented as means \pm standard deviation $(\mathrm{SD})$; $\mathrm{p}<0.05$ was considered statistically significant.

\section{RESULTS}

\section{Characteristics of the patients}

Before the addition of vildagliptin, all patients had high levels of HbAlc (range, 7.7\% - 12.4\%; mean, 9.30 \pm 1.38 ) and FPG (range, $146-332 \mathrm{mg} / \mathrm{dL}$; mean, $179.63 \pm 52.34)$. Patient BMI ranged from 24.7 to $37.9 \mathrm{~kg} / \mathrm{m}^{2}$ (mean, $28.30 \pm 2.61$ ) (Tables 1 and 2 ). 
Table 1. Characteristics of the patients before and after addition of vildagliptin

\begin{tabular}{|c|c|c|c|c|c|c|c|}
\hline Patients (sex) & $\begin{array}{l}\text { Patients BMI } \\
\left(\mathbf{k g} / \mathbf{m}^{2}\right)\end{array}$ & $\begin{array}{c}\text { Time (in years) } \\
\text { from diagnosis } \\
\text { of type } 2 \\
\text { diabetes }\end{array}$ & $\begin{array}{l}\text { FPG before } \\
\text { addition of } \\
\text { vildagliptin } \\
\text { (mg/dL) }\end{array}$ & $\begin{array}{c}\text { FPG after } \\
\text { addition of } \\
\text { vildagliptin } \\
\text { (mg/dL) }\end{array}$ & $\begin{array}{l}\text { HbA1c before } \\
\text { addition of } \\
\text { vildagliptin } \\
\text { (\%) }\end{array}$ & $\begin{array}{l}\text { HbA1c after } \\
\text { addition of } \\
\text { vildagliptin } \\
\text { (\%) }\end{array}$ & $\begin{array}{l}\text { Length of TOT } \\
\text { (months) }\end{array}$ \\
\hline 1. FDA (female) & 24.7 & 6.2 & 146 & 119 & 7.7 & 6.1 & 7.0 \\
\hline 2. DAC (male) & 27.2 & 4.3 & 149 & 114 & 8.3 & 6.8 & 6.0 \\
\hline 3. ACC (female) & 26.6 & 7.1 & 155 & 112 & 8.5 & 6.9 & 14.0 \\
\hline 4. SFS (male) & 31.5 & 9.7 & 156 & 119 & 7.9 & 6.7 & 12.0 \\
\hline 5. GCM (male) & 37.9 & 8.1 & 183 & 132 & 8.6 & 6.2 & 7.0 \\
\hline 6. FCS (female) & 31.6 & 10.4 & 178 & 112 & 11.2 & 6.4 & 11.0 \\
\hline 7. JAB (male) & 27.6 & 5.7 & 332 & 116 & 11.5 & 6.6 & 15.0 \\
\hline 8. MZN (male) & 27.6 & 6.3 & 168 & 119 & 7.9 & 6.5 & 10.0 \\
\hline 9. BSG (female) & 28.4 & 7.7 & 188 & 115 & 8.5 & 6.7 & 9.0 \\
\hline 10. QNP (female) & 28.2 & 6.4 & 160 & 118 & 7.8 & 6.5 & 8.0 \\
\hline 11. FWL (male) & 27.7 & 5.3 & 161 & 118 & 7.8 & 6.5 & 9.0 \\
\hline 12. VCAF (male) & 27.9 & 6.2 & 188 & 154 & 9.4 & 7.9 & 12.0 \\
\hline 13. MGC (female) & 25.8 & 7.4 & 192 & 166 & 10.5 & 8.6 & 9.0 \\
\hline 14. MJS (female) & 29.3 & 8.8 & 166 & 134 & 8.4 & 7.7 & 7.0 \\
\hline 15. AFP (male) & 28.3 & 9.6 & 177 & 154 & 8.5 & 7.6 & 8.0 \\
\hline 16. SFA (female) & 26.3 & 7.7 & 166 & 139 & 8.8 & 7.7 & 6.0 \\
\hline 17. GBD (female) & 26.1 & 10.0 & 175 & 148 & 8.6 & 7.7 & 6.0 \\
\hline 18. MFA (male) & 26.2 & 10.4 & 166 & 138 & 8.1 & 7.5 & 7.0 \\
\hline 19. SCA (female) & 25.8 & 6.4 & 278 & 187 & 10.5 & 9.1 & 6.0 \\
\hline 20. MAV (female) & 27.3 & 4.5 & 252 & 172 & 10.8 & 9.5 & 8.0 \\
\hline 21. RSS (male) & 27.8 & 4.8 & 202 & 177 & 9.9 & 8.4 & 6.0 \\
\hline 22. RAS (female) & 28.4 & 4.3 & 182 & 151 & 8.6 & 7.7 & 8.0 \\
\hline 23. MFRS (female) & 30.3 & 6.5 & 176 & 132 & 8.4 & 7.5 & 8.0 \\
\hline 24. MGC (female) & 28.8 & 4.4 & 157 & 120 & 7.9 & 7.2 & 12.0 \\
\hline 25. MLS (female) & 28.1 & 4.8 & 173 & 137 & 8.4 & 7.5 & 8.0 \\
\hline 26. MBL (male) & 27.4 & 5.6 & 268 & 213 & 12.4 & 10.4 & 6.0 \\
\hline 27. LBC (female) & 25.4 & 3.8 & 144 & 127 & 8.4 & 7.6 & 8.0 \\
\hline 28. MRG (male) & 31.6 & 5.3 & 174 & 140 & 8.9 & 7.7 & 7.0 \\
\hline 29. DMC (female) & 34.7 & 14.8 & 190 & 123 & 10.2 & 7.8 & 7.0 \\
\hline 30. DWS (male) & 27.8 & 9.6 & 218 & 167 & 11.6 & 8.8 & 6.0 \\
\hline 31. MPS (female) & 28.8 & 7.2 & 181 & 156 & 9.6 & 8.3 & 6.0 \\
\hline 32. GSS (female) & 30.6 & 7.6 & 204 & 167 & 11.4 & 7.7 & 8.0 \\
\hline 33. JRP (male) & 28.4 & 6.8 & 169 & 122 & 8.4 & 7.4 & 7.0 \\
\hline 34. MSC (female) & 27.8 & 7,2 & 222 & 182 & 12.1 & 10.1 & 6.0 \\
\hline 35. ATF (male) & 24.8 & 5,8 & 180 & 162 & 9.4 & 8.4 & 6.0 \\
\hline 36. RCS (male) & 26.8 & 6.6 & 169 & 144 & 8.5 & 7.4 & 12.0 \\
\hline 37. NGS (male) & 26.7 & 8.2 & 192 & 167 & 10.1 & 8.5 & 6.0 \\
\hline
\end{tabular}

FPG: fasting plasma glucose; TOT: triple oral therapy.

\section{Efficacy of triple oral therapy}

Length of triple oral therapy ranged from 6 to 15 months (mean, $8.18 \pm 2.37$ ). As shown in table 2 , triple oral therapy (TOT) resulted in significant reduction in mean FPG and HbAlc. Indeed, mean HbAlc le- vels decreased from $9.30 \pm 1.38$ to $7.71 \pm 1.06 \%(\mathrm{p}<$ $0.001)$, whereas FPG decreased from $186.84 \pm 39.34$ to $141.59 \pm 39.72 \mathrm{mg} / \mathrm{dL}(\mathrm{p}<0.001)$. However, TOT had a neutral effect on BMI, which did not change significantly. After vildagliptin was added (50 mg twice a 
day), HbAlc levels fell 7\% in 11 patients (29.7\%), 6 women and 5 men. In the remaining patients, mean absolute reduction in $\mathrm{HbAlc}$ was $1.47 \pm 0.60 \%$ (range, 0.7-2.9). Moreover, FPG levels $<120 \mathrm{mg} / \mathrm{dL}$ were observed in 12 patients $(32.4 \%)$, with mean reduction of $20.00 \pm 6.23 \mathrm{mg} / \mathrm{dL}$ (range, 11.81-35.26) in the remaining subjects. Finally, both $\mathrm{HbAlc}<7 \%$ and FPG $<120 \mathrm{mg} / \mathrm{dL}$ were observed in 10 patients $(27.0 \%)$. As shown in table 3 and figure 1 , there was a statistically significant reduction $(\mathrm{p}<0.01)$ in FPG and HbAlc levels in responsive patients, after the addition of vildagliptin.

Table 2. BMl and parameters of glycemic control before and after addition of vildagliptin

\begin{tabular}{lccc}
\hline & Baseline* $^{*}$ & $\begin{array}{c}\text { After vildagliptin } \\
\text { addition }\end{array}$ & p-value \\
\hline HbA1C $(\%)$ & $\begin{array}{c}9.30 \pm 1.38 \\
(\text { range, } 7.7-12.4)\end{array}$ & $\begin{array}{c}7.71 \pm 1.06 \\
(\text { range, 6.1-10.4) }\end{array}$ & $<0.001$ \\
Fasting plasma & $186.84 \pm 39.34$ & $141.59 \pm 39.72$ & $<0.001$ \\
glucose $(\mathrm{mg} / \mathrm{dL})$ & $($ range, $144-332)$ & $($ range, 114-213) & \\
BMI $\left(\mathrm{kg} / \mathrm{m}^{2}\right)$ & $\begin{array}{c}28.30 \pm 2.61 \\
(\text { range, 24.7-37.9) }\end{array}$ & $\begin{array}{c}27.24 \pm 1.96 \\
(\text { range, 25.2-35.1) }\end{array}$ & 0.163 \\
\hline
\end{tabular}

Table 3. Behavior of glycemic parameters in responsive patients before and after addition of vildagliptin

\begin{tabular}{lccc}
\hline & $\begin{array}{c}\text { Before } \\
\text { vildagliptin }\end{array}$ & After vildagliptin & p-value \\
\hline $\begin{array}{l}\text { HbA1C }(\%) \\
(\mathrm{n}=11)\end{array}$ & $\begin{array}{c}8.71 \pm 1.37 \\
(\text { range, } 7.7-11.6)\end{array}$ & $\begin{array}{c}6.50 \pm 0.26 \\
(\text { range, } 6.1-6.9)\end{array}$ & $<0.01$ \\
$\begin{array}{l}\text { Fasting plasma } \\
\text { glucose (mg/dL) } \\
(\mathrm{n}=12)\end{array}$ & $\begin{array}{c}179.63 \pm 52.34 \\
(\text { range, 146-332) }\end{array}$ & $\begin{array}{c}116.50 \pm 2.67 \\
(\text { range, 112-119) }\end{array}$ & $<0.01$ \\
\hline
\end{tabular}

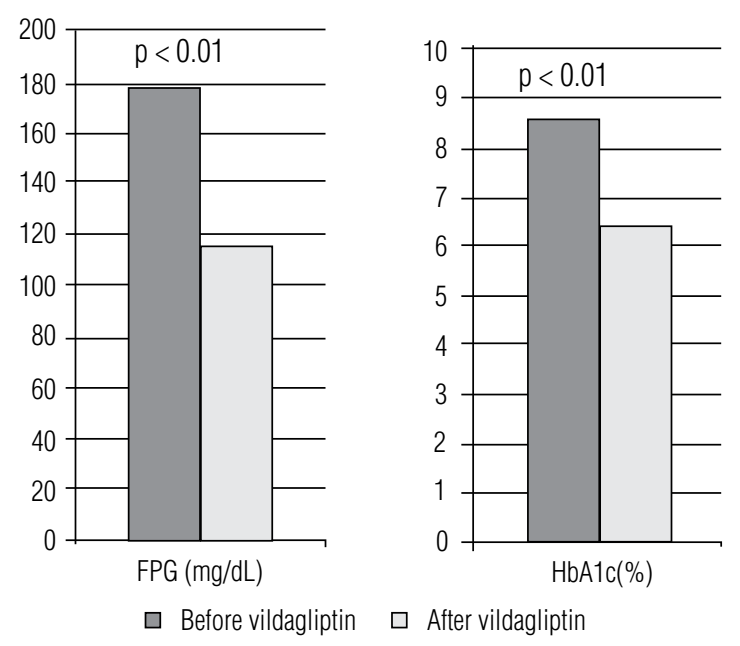

Figure 1. Fasting plasma glucose (FPG) and $\mathrm{HbA1c}$ levels in responsive patients before and after addition of vildagliptin.
In comparison with nonresponsive subjects, responsive patients (those who reached HbAlc levels < 7\%) had significantly lower mean FPG levels (179.63 \pm 52.34 vs. $189.88 \pm 33.17 \mathrm{mg} / \mathrm{mL} ; \mathrm{p}<0.001)$. However, there was considerable overlap between responsive and nonresponsive patients (Table 4). Mean HbAlc values were also lower $(8.71 \pm 1.37$ vs. $9.50 \% \pm 1.34 \%)$, but the difference between groups was not statistically significant $(\mathrm{p}<0.067)$. Similarly, baseline BMI and time from diagnosis of type 2 diabetes did not differ in both groups (Table 4 ).

Table 4. Comparison of patients responsible and nonresponsible to triple oral therapy

\begin{tabular}{|c|c|c|c|}
\hline & $\begin{array}{l}\text { Responsive } \\
\text { patients } \\
(\mathrm{n}=11)\end{array}$ & $\begin{array}{c}\text { Nonresponsive } \\
\text { patients }(n=26)\end{array}$ & p-value \\
\hline $\begin{array}{l}\text { Baseline* HbA1c } \\
(\%)\end{array}$ & $\begin{array}{c}8.71 \pm 1.37 \\
\text { (range, } 7.7-11.6 \text { ) }\end{array}$ & $\begin{array}{c}9.50 \pm 1.34 \\
\text { (range, } 7.9-12.4 \text { ) }\end{array}$ & 0.067 \\
\hline $\begin{array}{l}\text { Baseline* fasting } \\
\text { plasma glucose } \\
\text { (mg/dL) }\end{array}$ & $\begin{array}{c}179.63 \pm 52.34 \\
\text { (range, 146-332) }\end{array}$ & $\begin{array}{c}189.88 \pm 33.17 \\
\text { (range, } 144-278)\end{array}$ & $<0.001$ \\
\hline $\begin{array}{l}\text { Baseline }{ }^{*} \text { BMl } \\
\left(\mathrm{kg} / \mathrm{m}^{2}\right)\end{array}$ & $\begin{array}{c}29.0 \pm 3.55 \\
\text { (range, 24.7-37.9) }\end{array}$ & $\begin{array}{c}28.01 \pm 2.11 \\
\text { (range, } 24.8-34.7 \text { ) }\end{array}$ & 0.089 \\
\hline $\begin{array}{l}\text { Time (in years) } \\
\text { from diagnosis } \\
\text { of type } 2 \\
\text { diabetes }\end{array}$ & $\begin{array}{c}7.01 \pm 1.84 \\
\text { (range, } 4.3-10.4 \text { ) }\end{array}$ & $\begin{array}{c}7.86 \pm 2.64 \\
\text { (range, } 4.4-15.2 \text { ) }\end{array}$ & 0.148 \\
\hline
\end{tabular}

* Prior to the addition of vildagliptin.

\section{DISCUSSION}

Vildagliptin is a new oral antidiabetic drug that acts as a potent and selective inhibitor of DPP-4, the enzyme responsible for the rapid degradation of circulating GLP-1 $(7,12,13)$. Early studies suggested that vilgagliptin improves islet function in patients with type 2 diabetes by increasing both $\alpha$ - and $\beta$-cells responsiveness to glucose $(17,18)$. Vildagliptin may be used as monotherapy, but better results are found when it is combined with metformin $(12,13)$. Recent studies have shown that, as add-on therapy in patients with inadequately controlled T2DM treated with metformin, vildagliptin was as effective as TZDs (19) and sulphonylureas $(20,21)$. In the present study, we observed that addition of vildagliptin to an unsuccessful combination of metformin with sulphonylurea was able to reduce $\mathrm{HbAlc}$ to $<7.0 \%$ in $29.7 \%$ of patients with T2DM.

According to the guidelines of the American Diabetes Association (ADA), metformin should be started together with lifestyle interventions in the manage- 
ment of type 2 diabetic patients, unless contraindicated $(9,15)$. When a second drug is needed, most endocrinologists will choose a sulphonylurea $(7,16)$. TZDs and DPP-4 inhibitors are other options $(9,13)$. The most commonly used triple oral therapy includes the combination of metformin with a sulphonylurea and a $\operatorname{TZD}(7,9,16,22)$. This treatment regimen is more likely to be successful when HbAlc levels are $<9.5 \%$ before the addition of the third drug $(7,16,22,23)$.

Rosenstock and cols. (23) evaluated the efficacy and safety of add-on insulin glargine versus rosiglitazone in 217 insulin-naïve patients with inadequately controlled type 2 diabetes on dual oral therapy with sulfonylurea and metformin (HbAlc 7.5\%-11\%). At the end of the study, $\mathrm{HbAlc}$ was reduced by $1.66 \%$ from baseline in the insulin glargine group, and by $1.51 \%$ in the rosiglitazone group, with no significant difference between the groups $(\mathrm{p}=0.1446)$. In patients with $\mathrm{HbAlc}$ $<9.5 \%$ there was no significant difference between treatment groups $(\mathrm{p}=0.87)$. However, glargine resulted in significantly greater $\mathrm{HbAlc}$ reduction compared with rosiglitazone, when baseline $\mathrm{HbAlc}$ levels were $\geq$ $9.5 \%(\mathrm{p}=0.05)$. Overall, HbAlc of $\leq 7 \%$ was achieved in $48 \%$ of insulin glargine-treated patients, and $49 \%$ of rosiglitazone-treated patients (23).

Potential advantages of DPP-4 inhibitors over TZDs include a neutral effect on body weight and better tolerability profile, without fluid retention, peripheral edema, and cardiovascular, hematological or osteometabolic adverse events $(7,11-13,24)$. Conversely, in clinical trials, the incidence of TZDs-associated edema varied from about $3.0 \%$ to $7.5 \%$, compared with $1.0 \%$ to $2.5 \%$ with placebo or other oral glucose-lowering agents (25). Weight gain induced by TZDs is usually modest (mean of $3.6 \mathrm{~kg}$ ) but it may be excessive, leading to discontinuation of treatment (26). TZDs are also associated with an increased incidence of fractures in women, and perhaps in men $(15,27,28)$. Large trials, such as RECORD (26) and PROactive (26), showed that the use of TZDs results in a twofold increased risk for congestive heart failure. Moreover, two meta-analyses have suggested a $30 \%-40 \%$ relative increase in risk for myocardium infarction in type 2 diabetic patients treated with rosiglitazone $(29,30)$. In the RECORD study, a non-statistically significant increased risk for myocardium infarction was noted in the rosiglitazone group (HR 1.14, 0.80-1.63) (28). Nevertheless, low event rates might have precluded statistical confirmation of significant risk, if present. Also, rosiglitazone therapy was associated with higher
LDL-c levels, leading to an increased use of statins in the rosiglitazone group, which might have reduced the incidence of cardiovascular events (31). Finally, TZDs are about 3 percent more likely to cause anemia (hematocrit drop of 1-3 percent) than the other oral hypoglycemic agents $(7,25)$. Rosiglitazone was recently removed from the market in Brazil, Europe and the USA.

In our study, compared to nonresponsive subjects, responsive patients (those who achieved HbAlc levels $<7 \%$ after the addition of vildagliptin) had lower baseline fasting plasma glucose and $\mathrm{HbAlc}$ levels. However, the difference was only statistically significant for fasting plasma glucose. Moreover, there was considerable overlap between the two groups, which prevented the prediction of which patients would be responsive to triple oral therapy. Finally, the rate of responsive patients was apparently not influenced by BMI, sex, and time from T2DM diagnosis.

A likely limitation of our study is the small number of patients evaluated. However, to the best of our knowledge, this is first published trial that assessed triple oral therapy for T2DM with a DPP-4 inhibitor.

In conclusion, our preliminary results demonstrated that triple oral therapy with metformin, a sulphonylurea and vildagliptin may be an appropriate approach for some type 2 diabetic patients who are irresponsive to the combination of metformin with a sulfonylurea. BMI and time from diagnosis of type 2 diabetes mellitus apparently do not influence responsiveness to triple oral therapy. However, further studies with a larger number of patients are needed on the subject.

Disclosure: no potential conflict of interest relevant to this article was reported.

\section{REFERENCES}

1. Defronzo RA. Banting lecture. From the triumvirate to the ominous octet: a new paradigm for the treatment of type 2 diabetes mellitus. Diabetes. 2009;58(4):773-95.

2. Mizuno CS, Chittiboyina AG, Kurtz TW, Pershadsingh HA, Avery MA. Type 2 diabetes and oral antihyperglycemic drugs. Curr Med Chem. 2008;15(1):61-74.

3. Wajchenberg BL. Beta -cell failure in diabetes and preservation by clinical treatment. Endocr Rev. 2007;28(2):187-218.

4. Freeman JS. Role of the incretin pathway in the pathogenesis of type 2 diabetes mellitus. Cleve Clin J Med. 2009;76 Suppl 5:S12-9.

5. McGill JB. Impact of incretin therapy on islet dysfunction: an underlying defect in the pathophysiology of type 2 diabetes. Postgrad Med. 2009;121(1):46-58.

6. Drucker DJ, Nauck MA. The incretin system: glucagon-like peptide-1 receptor agonists and dipeptidyl peptidase-4 inhibitors in type 2 diabetes. Lancet. 2006;368(9548):1696-705. 
7. Mattheus DR, Ahmed S, Lyra R, Vilar L. In: Vilar L, et al., editors. Endocrinologia clínica, 4th ed. Rio de Janeiro: Guanabara Koogan; 2009. p. 622-41.

8. Nathan DM, Buse JB, Davidson MB, Ferrannini E, Holman RR, Sherwin R, et al.; American Diabetes Association; European Association for Study of Diabetes. Medical management of hyperglycemia in type 2 diabetes: a consensus algorithm for the initiation and adjustment of therapy: a consensus statement of the American Diabetes Association and the European Association for the Study of Diabetes. Diabetes Care. 2009;32(1):193-203.

9. Rodbard HW, Jellinger PS, Davidson JA, Einhorn D, Garber AJ, Grunberger G, et al. Statement by an American Association of Clinical Endocrinologists/American College of Endocrinology consensus panel on type 2 diabetes mellitus: an algorithm for glycemic control. Endocr Pract. 2009;15(6):540-59. Erratum in: Endocr Pract. 2009;15(7):768-70.

10. Vilar L, Canadas V, Arruda MJ, Arahata C, Agra R, Pontes L, et al. Comparison of metformin, gliclazide MR and rosiglitazone in monotherapy and in combination for type 2 diabetes. Arq Bras Endocrinol Metabol. 2010;54(3):311-8.

11. Neumiller JJ, Wood L, Campbell RK. Dipeptidyl peptidase-4 inhibitors for the treatment of type 2 diabetes mellitus. Pharmacotherapy. 2010;30(5):463-84.

12. Rosenstock J, Fitchet M. Vildagliptin: clinical trials programme in monotherapy and combination therapy for type 2 diabetes. Int $\mathrm{J}$ Clin Pract Suppl. 2008;(159):15-23.

13. Davidson JA. Advances in therapy for type 2 diabetes: GLP-1 receptor agonists and DPP-4 inhibitors. Cleve Clin J Med. 2009;76 Suppl 5:S28-38.

14. Mavian AA, Miller S, Henry RR. Managing type 2 diabetes: balancing HbA1c and body weight. Postgrad Med. 2010;122(3):106-17.

15. Nathan DM, Buse JB, Davidson MB, Heine RJ, Holman RR, Sherwin $\mathrm{R}$, et al. Management of hyperglycemia in type 2 diabetes: a consensus algorithm for the initiation and adjustment of therapy: a consensus statement the American Diabetes Association and the European Association for the Study of Diabetes. Diabetes Care. 2006;29(8):1963-72.

16. Krentz AJ, Bailey CJ. Oral antidiabetic agents: current role in type 2 diabetes mellitus. Drugs. 2005;65(3):385-411.

17. Kleppinger EL, Helms $\mathrm{K}$. The role of vildagliptin in the management of type 2 diabetes mellitus. Ann Pharmacother. 2007;41(5):824-32.

18. Balas B, Baig MR, Watson C, Dunning BE, Ligueros-Saylan M, Wang $Y$, et al. The dipeptidyl peptidase IV inhibitor vildagliptin suppresses endogenous glucose production and enhances islet function after single-dose administration in type 2 diabetic patients. J Clin Endocrinol Metab. 2007;92(4):1249-55.
19. Purkayastha D, Baron M. Comparison of vildagliptin and thiazolidinedione as add-on therapy in patients inadequately controlled with metformin: results of the GALIANT trial--a primary care, type 2 diabetes study. Diabetes Obes Metab. 2009;11(10):978-86.

20. Matthews DR, Dejager S, Ahren B, Fonseca V, Ferrannini E, Couturier $A$, et al. Vildagliptin add-on to metformin produces similar efficacy and reduced hypoglycaemic risk compared with glimepiride, with no weight gain: results from a 2-year study. Diabetes Obes Metab. 2010;12(9):780-9.

21. Filozof C, Gautier JF. A comparison of efficacy and safety of vildagliptin and gliclazide in combination with metformin in patients with Type 2 diabetes inadequately controlled with metformin alone: a 52-week, randomized study. Diabet Med. 2010;27(3):318-26.

22. Bell DS, Ovalle F. Long-term efficacy of triple oral therapy for type 2 diabetes mellitus. Endocr Pract. 2002;8(4):271-5.

23. Rosenstock J, Sugimoto D, Strange P, Stewart JA, Soltes-Rak E, Dailey G. Triple therapy in type 2 diabetes: insulin glargine or rosiglitazone added to combination therapy of sulfonylurea plus metformin in insulin-naive patients. Diabetes Care. 2006;29(3):554-9.

24. Schweizer A, Dejager S, Foley JE, Kothny W. Assessing the general safety and tolerability of vildagliptin: value of pooled analyses from a large safety database versus evaluation of individual studies. Vasc Health Risk Manag. 2011;7:49-57.

25. Yki-Järvinen H.Thiazolidinediones. N Engl J Med. 2004;351(11):1106-8.

26. Dormandy JA, Charbonnel B, Eckland DJ, Erdmann E, Massi-Benedetti M, Moules IK, et al.; PROactive investigators. Secondary prevention of macrovascular events in patients with type 2 diabetes in the PROactive Study (PROspective pioglitAzone Clinical Trial In macroVascular Events): a randomised controlled trial. Lancet. 2005;366(9493):1279-89.

27. Home PD, Pocock SJ, Beck-Nielsen H, Curtis PS, Gomis R, Hanefeld $M$, et al.; RECORD Study Team. Rosiglitazone evaluated for cardiovascular outcomes in oral agent combination therapy for type 2 diabetes (RECORD): a multicentre, randomised, open-label trial. Lancet. 2009;373(9681):2125-35.

28. Kahn SE, Zinman B, Lachin JM, Herman WH, Holman RR, Kravitz BG, et al.; Diabetes Outcome Progression Trial (ADOPT) Study Group. Rosiglitazone-associated fractures in type 2 diabetes: an Analysis from A Diabetes Outcome Progression Trial (ADOPT). Diabetes Care. 2008;31(5):845-51.

29. Nissen SE, Wolski K. Effect of rosiglitazone on the risk of myocardial infarction and death from cardiovascular causes. N Engl J Med. 2007;356(24):2457-71. [Erratum, N Engl J Med. 2007;357(1):100.]

30. Singh S, Loke YK, Furberg CD. Long-term risk of cardiovascular events with rosiglitazone: a meta-analysis. JAMA. 2007;298(10):1189-95.

31. Retnakaran R, Zinman B. Thiazolidinediones and clinical outcomes in type 2 diabetes. Lancet. 2009;373(9681):2088-90. 